\title{
IMPLEMENTASI DATA MINING MENGGUNAKAN METODE APRIORI PADA TRANSAKSI PENJUALAN BARANG (STUDI KASUS DI CHORUS MINIMARKET)
}

\author{
Erika Silvia Sihombing, Anton Setiawan Honggowibowo, Dwi Nugraheny \\ Jurusan Teknik Informatika \\ Sekolah Tinggi Teknologi Adisutjipto Yogyakarta \\ informatika@stta.ac.id
}

\begin{abstract}
Minimarket chorus is where the sale of goods that have sales transaction data is large daily. Sale of transaction data in the Chorus Minimarket in store are usually only used as an archive only and not in the know what the benefits of a large sale of transaction data for later. The technique of data mining can help analyze of transactions data large that is stored in database and can give benefits in the sale of items.

Data mining process will be done is to extract the knowledge from very large data amount of and can then retrieve the information from these data. In this research, which used data mining with association rules is apriori method. Apriori method is used to find association patterns with a certain confidence level. Association rules used to know and give of information to find items is often be purchased together by customers.

The data mining was be implemented by using Borland Delphi software and PostgreSQL databases to get information about the patterns of association rules from transaction data of item in the sale of Chorus Minimarket. Expected to application of data mining can provide benefits for the Chorus Minimarket later.
\end{abstract}

Keyword : Implementation, Data Mining, Apriori Method, Sales Items.

\section{Pendahuluan}

Minimarket merupakan tempat penjualan barang kebutuhan sehari-hari. Banyaknya pesaing dalam bisnis khususnya pada minimarket ini menuntut para pengembang untuk menemukan strategi yang dapat meningkatkan penjualan barang, salah satunya dengan pemanfaatan data transaksi. Data transaksi ini dapat di olah menjadi informasi yang menguntungkan bagi minimarket itu sendiri. Hampir semua minimarket menggunakan sistem komputerisasi dalam menyimpan data penjualan. Data transaksi yang ada dalam database penjualan barang menyimpan jumlah record transaksi penjualan yang memiliki data yang sangat besar sehingga menyebabkan jumlah data terus menerus bertambah setiap harinya.

Jumlah data yang begitu besar dapat menjadi masalah bagi minimarket tersebut jika tidak dapat dimanfaatkan datanya. Banyak data yang sebenarnya dapat dikelola, tetapi tidak ada petunjuk untuk menggali data menjadi sebuah informasi. Biasanya data-data yang ada hanya di gunakan sebagai arsip bagi minimarket. Yang menjadi kendala dalam pengolahan informasi adalah apabila data-data transakasi yang ada dalam database penjualan dibiarkan begitu saja, sama halnya minimarket menumpuk data yang tidak di ketahui apa manfaat data 
itu bagi minimarket untuk di kemudian hari. Permasalahan di atas juga terjadi di Chorus Minimarket, sebagai suatu perusahaan penyedia barang-barang kebutuhan konsumen. Dalam hal ini, sangat di butuhkan aplikasi yang membantu minimarket untuk mendapatkan informasi. Salah satu cara untuk mendapatkan informasi tersebut adalah memanfaatkan teknik data mining dengan cara menganalisa data transaksi penjualan barang yang telah terjadi di minimarket sehingga didapatkan suatu kesimpulan tentang barang-barang apa yang biasanya dibeli oleh pelanggan secara bersamaan atau dapat disebut juga sebagai pola asosiasi. Teknik data mining yang digunakan dalam penelitian ini adalah apriori yang menggunakan analisis 2 nilai penting yaitu support dan confidence.

Apriori bertujuan untuk menemukan frequent itemset yang dijalankan pada sekumpulan data. Masalah utama pencarian Frequent Itemset adalah banyaknya jumlah kombinasi itemset yang harus diperiksa apakah memenuhi minimum support atau tidak. Apriori merupakan sebuah teknik data mining untuk menemukan aturan asosiasi (Association rules) yang berkenaan dengan studi tentang 'apa bersama apa' atau yang menghubungkan suatu kombinasi barang yang di gunakan untuk menemukan pola asosiasi dengan tingkat kepercayaan tertentu.

\section{Data Mining}

Menurut Turban (2005) data mining adalah proses yang menggunakan teknik statistic, matematika, artificial intelligence untuk ektrasi data dan mengidentifikasi informasi yang bermanfaat dan pengetahuan yang terkait dari berbagai database besar. Kata mining sendiri berarti usaha untuk mendapatkan sedikit barang berharga dari sejumlah besar material dasar. Data mining dengan proses bantuan komputer akan menggali data melalui analisis sekumpulan data yang besar dan kemudian mengambil inti atau arti dari suatu data.

Data mining adalah kegiatan menemukan pola yang menarik dari data dalam jumlah besar, data dapat disimpan dalam database. Definisi sederhana dari data mining adalah ekstraksi informasi atau pola yang penting atau menarik dari data yang ada di database yang besar. Data mining, sering juga disebut sebagai Knowledge Discovery in Database (KDD) yaitu kegiatan yang meliputi pengumpulan, pemakaian data, historis untuk menemukan keteraturan, pola atau hubungan dalam set data berukuran besar (Santoso, 2007). Data mining secara umum bisa juga di artikan sebagai teknologi yang sangat berguna untuk membantu perusahaan-perusahaan menemukan informasi yang sangat penting dari gudang data atau dapat juga disebut sebagai proses untuk menemukan pola yang bermakna dengan menyaring data yang sangat besar yang tersimpan dalam penyimpanan.

Berdasarkan beberapa pengertian tersebut dapat ditarik kesimpulan bahwa data mining adalah suatu teknik menggali informasi berharga yang terpendam atau tersembunyi pada suatu koleksi data (database) yang sangat besar sehingga ditemukan suatu pola yang menarik yang sebelumnya tidak diketahui. Dari definisi di atas hal penting yang terkait dengan data mining adalah:

1. Tujuan data mining untuk mendapatkan hubungan pola yang mungkin memberikan indikasi yang bermanfaat. 
2. Data yang akan diproses berupa data yang sangat besar.

3. Data mining merupakan proses otomatis terhadap data yang sudah ada.

\section{Karakteristik Data Mining}

Berikut ini merupakan karakteristik utama dari data mining, yaitu :

1. Data mining biasa menggunakan data yang sangat besar. Biasanya data yang besar digunakan untuk membuat hasil lebih dipercaya.

2. Data mining berhubungan dengan penemuan sesuatu yang tersembunyi dan pola data tertentu yang tidak diketahui sebelumnya.

Ada beberapa faktor yang menjadi alasan utama yang melatarbelakangi lahirnya data mining :

a. Keinginan untuk memanfaatkan data yang sangat besar tersebut sehingga dapat di peroleh nilai pengetahuan yang menyertai data yang besar.

b. Jumlah dan ukuran data yang di simpan dalam basis data sebuah organisasi terus bertambah dengan sangat cepat.

c. Perkembangan teknologi yang ada sangat memungkinkan untuk di terapkan sebagai teknik data mining dalam basis data yang besar.

d. Mampu menemukan suatu pola yang tidak terpikirkan sama sekali oleh penjualan.

e. Banyaknya data yang terkumpul sehingga memerlukan waktu yang sangat lama untuk menganalisinya.

\section{Apriori}

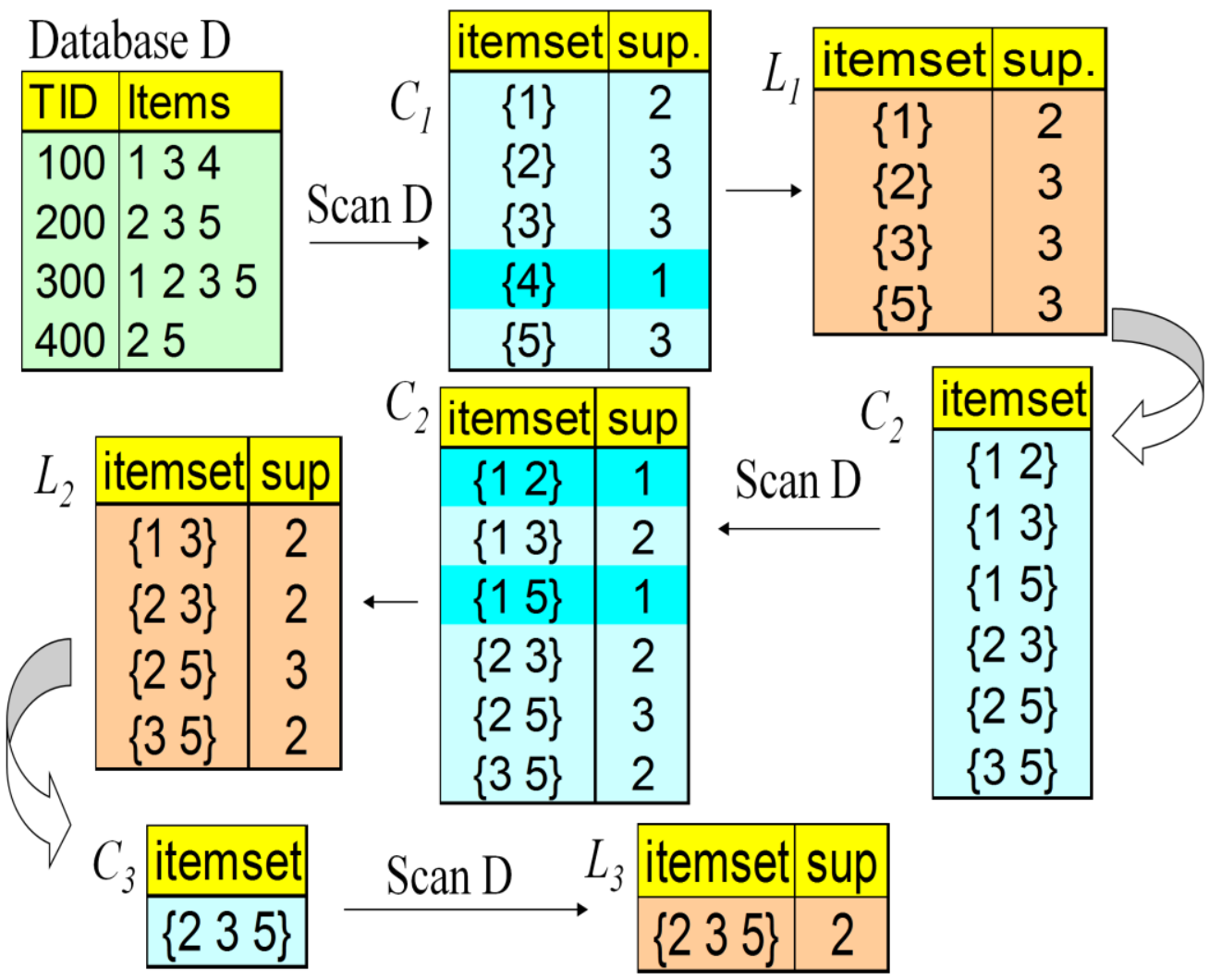

Gambar 1 Ilustrasi Apriori 
Apriori bertujuan untuk menemukan frequent itemsets yaitu itemset yang sering muncul pada setiap transaksi yang dijalankan pada sekumpulan data. Masalah utama pencarian Frequent Itemset adalah banyaknya jumlah kombinasi itemset yang harus diperiksa apakah memenuhi minimum support atau tidak. Salah satu cara untuk mengatasinya adalah dengan mengurangi jumlah kandidat itemset yang harus diperiksa. Apriori ini juga digunakan untuk mencari pola association rule yang baik dan memiliki nilai kepercayaan yang tinggi dan dapat juga digunakan untuk memproses jutaan data, menyeleksi data-data mana saja yang layak untuk diproses lebih lanjut sehingga menemukan beberapa rule. Apriori ini termasuk jenis aturan asosiasi pada data mining yang dapat diterapkan dalam memecahkan banyak masalah yang berhubungan dengan pengelompokan data, misalnya penerapan apriori untuk analisis data transaksi penjualan barang, dimana yang menjadi item-item dalam transaksi tersebut adalah barang yang dijual.

Apriori terdiri dari beberapa langkah yaitu menentukan data transaksi, menghitung jumlah total transaksi dan menentukan minimum support. Hal ini dilakukan oleh pengguna atau pihak perusahaan yang mengelola data transaksi. Mencari support untuk setiap 1-itemset pada data transaksi kemudian dibandingkan dengan minimum support yang sudah ditentukan sehingga ditemukan frequent 1-itemset (L1).

Kombinasikan L1 sehingga membentuk 2-itemset. Kombinasi item ini menghasilkan 2-itemset yang tiap set-nya memiliki dua item. Pertama dibuat kandidat 2-itemset dari kombinasi semua 1-itemset. Lalu untuk tiap kandidat 2itemset ini dihitung support-nya. Support artinya jumlah transaksi dalam database yang mengandung kedua item dalam kandidat 2-itemset. Seleksi frequent 2itemset (L2) sesuai dengan min support yang ditentukan. Setelah support dari semua kandidat 2-itemset didapatkan, kandidat 2-itemset yang memenuhi syarat minimum support dapat ditetapkan sebagai 2-itemset yang juga merupakan pola frekuensi tinggi. Apabila sudah ditemukan maka akan didapatkan asosiasi rule yang diinginkan oleh pengguna.

Prinsip Apriori adalah jika sebuah itemset infrequent, maka itemset yang infrequent tidak perlu lagi di explore supersetnya sehingga jumlah kandidat yang harus diperiksa menjadi berkurang. Dapat dilihat ilustrasi apriori di atas bahwa dengan menggunakan Apriori, jumlah kandidat yang harus diperiksa cukup banyak berkurang.

\section{Perancangan Sistem}

\section{Perancangan Diagram Alir Data}

Untuk mengetahui alur data yang ada di dalam suatu sistem, digunakan DAD untuk membuat suatu alur data program sehingga diketahui entitas-entitas yang terlibat, proses yang dibuat untuk menggambarkan dari mana asal data dan ke mana tujuan data yang keluar dari sistem, dimana data disimpan, proses apa yang menghasilkan data tersebut dan interaksi antara data yang tersimpan dan proses yang dikenakan pada data tersebut. Sehingga dengan DAD ini bisa diketahui dimana data disimpan dan bagaimana transformasi datanya. 


\section{Diagram Konteks}

Diagram konteks adalah diagram yang terdiri dari suatu proses dan menggambarkan ruang lingkup suatu sistem. Diagram konteks akan memberikan gambaran tentang keseluruhan system. Diagram konteks ini merupakan diagram untuk sistem penjualan pada transaksi penjualan. Terdapat 2 entitas, yang terdiri dari Operator dan Pimpinan. Operator bertugas mengisi data barang, data transaksi, min support yang dimasukkan ke sistem penjualan kemudian operator mengakses atau meneliti data tersebut. Dari data yang telah di akses, operator melaporkan hasil aturan asosiasi setiap harinya dan memberikan kepada pimpinan. Pimpinan menerima hasil laporan berupa nilai confidence dan aturan asosiasi. Diagram konteks ditunjukan pada gambar 2 .

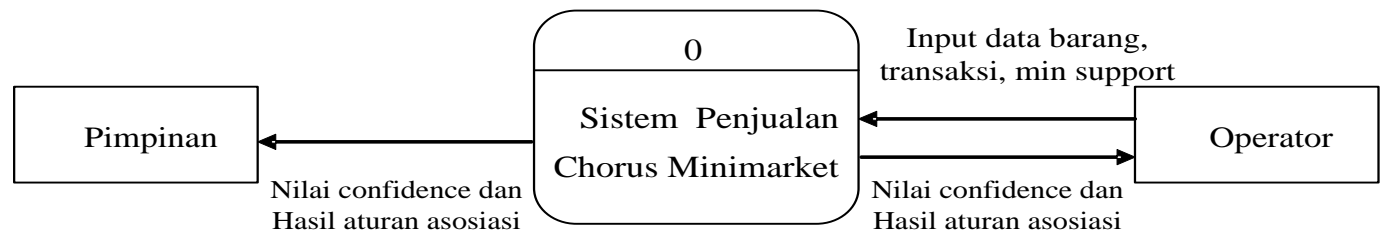

\section{Gambar 2 Diagram Konteks}

\section{DAD Level 1}

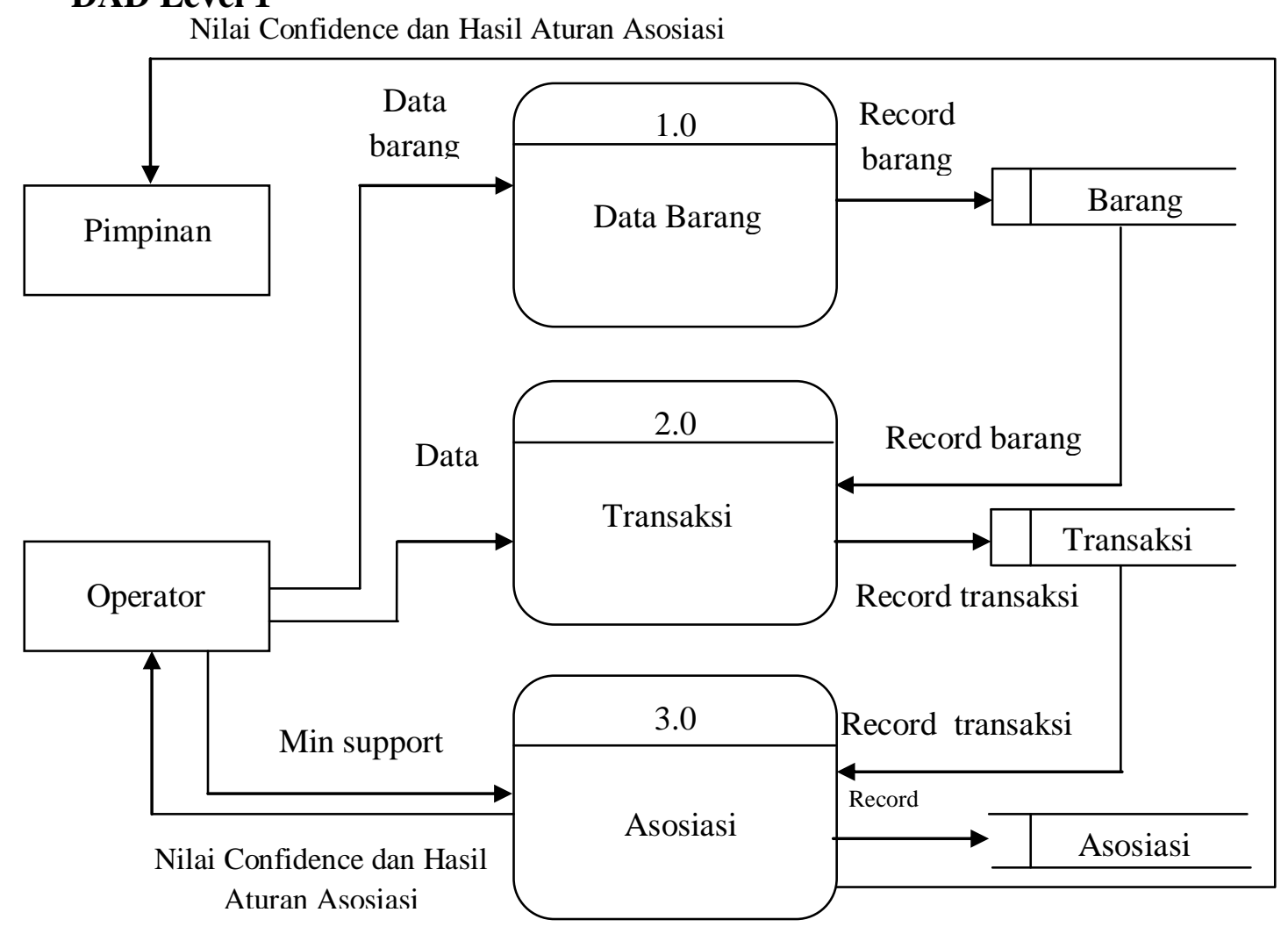

Gambar 3 DAD Level 1 
Diagram level 1 adalah diagram yang menggambarkan proses dari data flow diagram. Diagram level 1 memberikan pandangan secara menyeluruh mengenai sistem, menunjukkan fungsi-fungsi utama atau proses yang ada, aliran data, dan eksternal entity. Pada level ini sudah dimungkinkan digambarkannya data store yang digunakan.

\section{DAD Level 1 Proses Asosiasi}

Pada DAD Level 1 Proses Asosiasi, Operator melakukan proses pemasukan nilai min support. Nilai min support yang telah di masukkan akan melakukan proses pencarian k-itemset. K-itemset yang sudah ditemukan akan membentuk aturan-aturan asosiasi yang menghasilkan nilai confidence dan hasil aturan asosiasi. Operator dan juga Pimpinan akan mendapatkan nilai confidence dan hasil aturan asosiasi. DAD Level 1 Proses Asosiasi, dapat dilihat pada gambar 4.

Nilai Confidence dan

Hasil Aturan Asosiasi

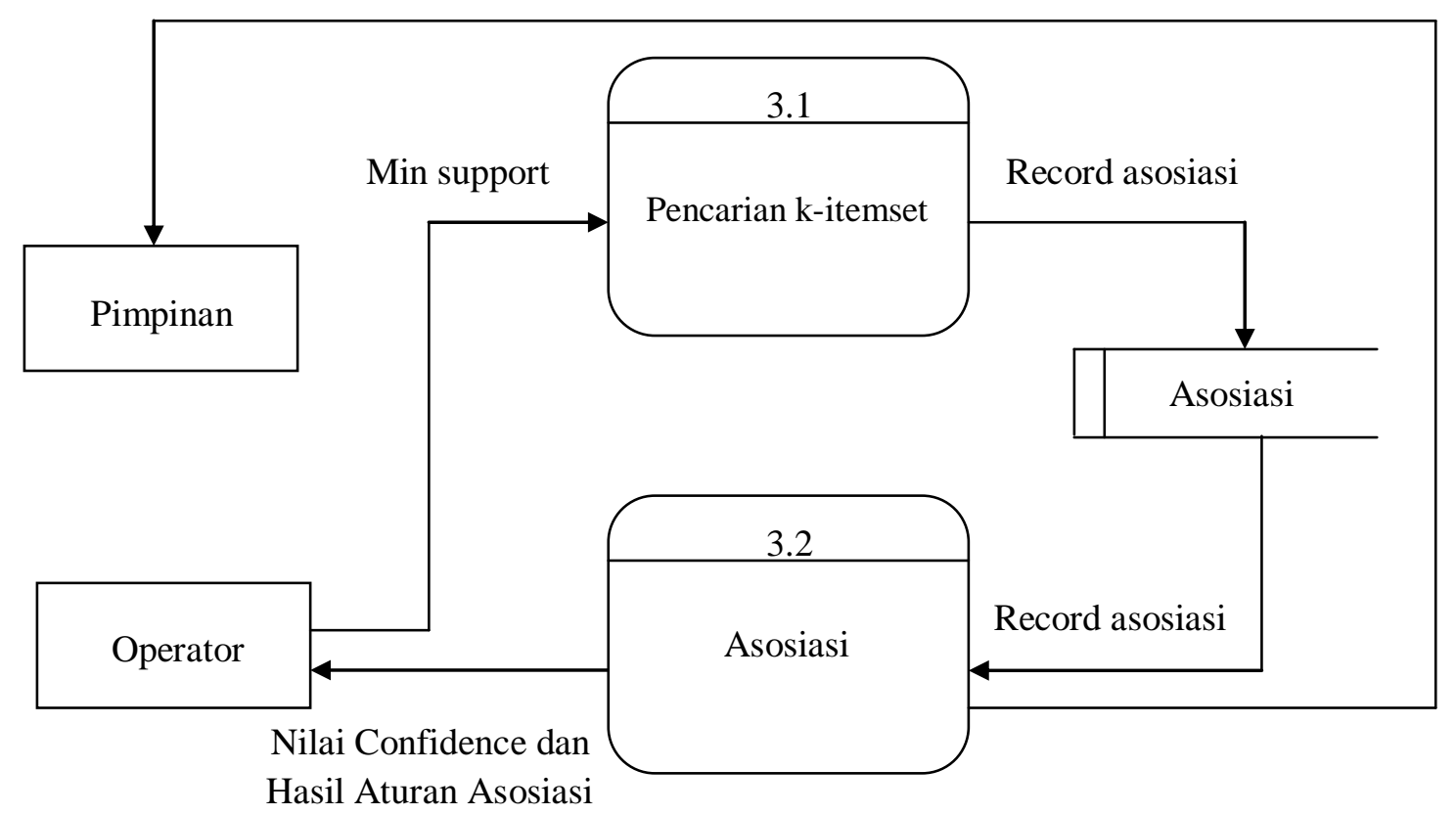

Gambar 4 DAD Level 1 Proses Asosiasi

\section{FlowChart Sistem}

Dalam membuat suatu sistem yang sistematis, diperlukannya suatu Flowchart sistem untuk melihat proses aliran data yang ada dari awal sampai selesai. 


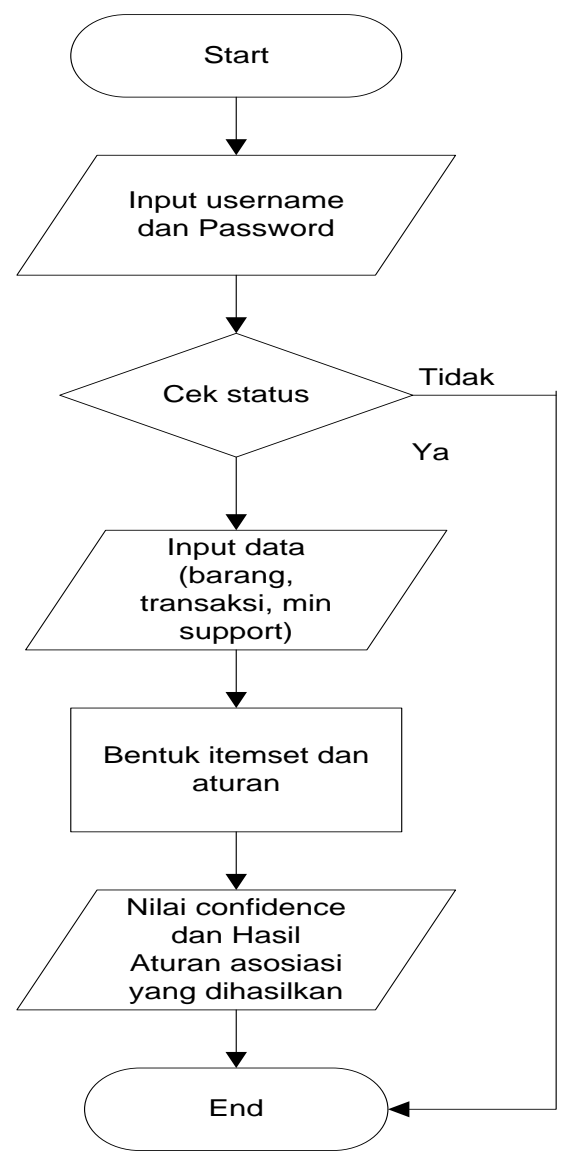

Gambar 5 Flowchart

\section{Relasi Antar Tabel}

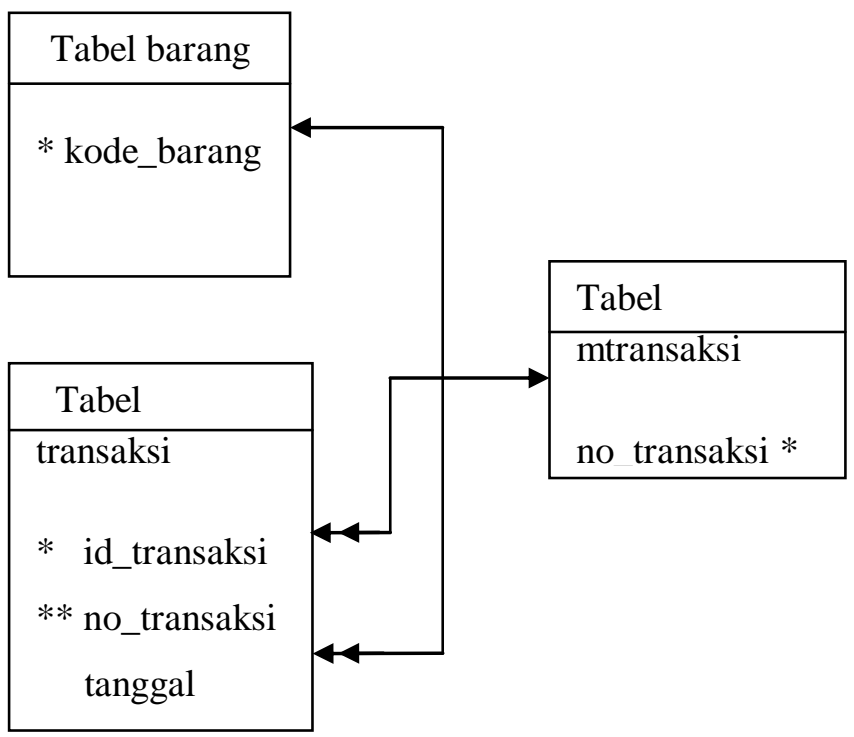

Gambar 6 Relasi Antar Tabel 
Relasi antar tabel merupakan hasil dari perancangan basis data menggunakan model basis data relasional yang membentuk struktur relasi yang baik. Dengan relasi yang baik, akan diperoleh gambaran umum jalannya sistem. Relasi antar tabel ini merupakan alat bantu dalam menentukan langkah-langkah kerja yang akan dilakukan oleh programmer, dimulai dari proses pemasukan data, pembentukan tabel sampai dengan pembentukan laporan-laporan sesuai dengan permasalahan pada sistem yang akan dibuat. Relasi database pada Penerapan Data Mining Menggunakan Apriori Pada Transaksi Penjualan Barang dapat dilihat pada gambar 6.

\section{Implementasi Dan Analisa Sistem}

Implementasi sistem merupakan tahap pendiskripsian suatu sistem agar sistem tersebut siap untuk dioperasikan sesuai dengan yang diharapkan. Tahap implementasi ini akan membahas mengenai desain input data, desain proses data, desain output sistem serta analisis hasil yang berupa pengujian sistem tersebut secara manualnya. Dalam implementasi sistem ini dapat diketahui cara kerja suatu sistem yang dijalankan, apakah telah berjalan dengan baik atau tidak. Untuk mengetahuinya program ini di buat dengan menggunakan delphi 7 dan menggunakan database PostgreSQL.

\section{Implementasi Menu Apriori}

Dalam implementasi aplikasi Data mining menggunakan apriori pada transaksi penjualan barang di Chorus Minimarket ini, terdapat menu Apriori yang terdiri dari sub menu Perhitungan Apriori dan Import Data. Tampilan menu Apriori, dapat dilihat pada gambar 7.

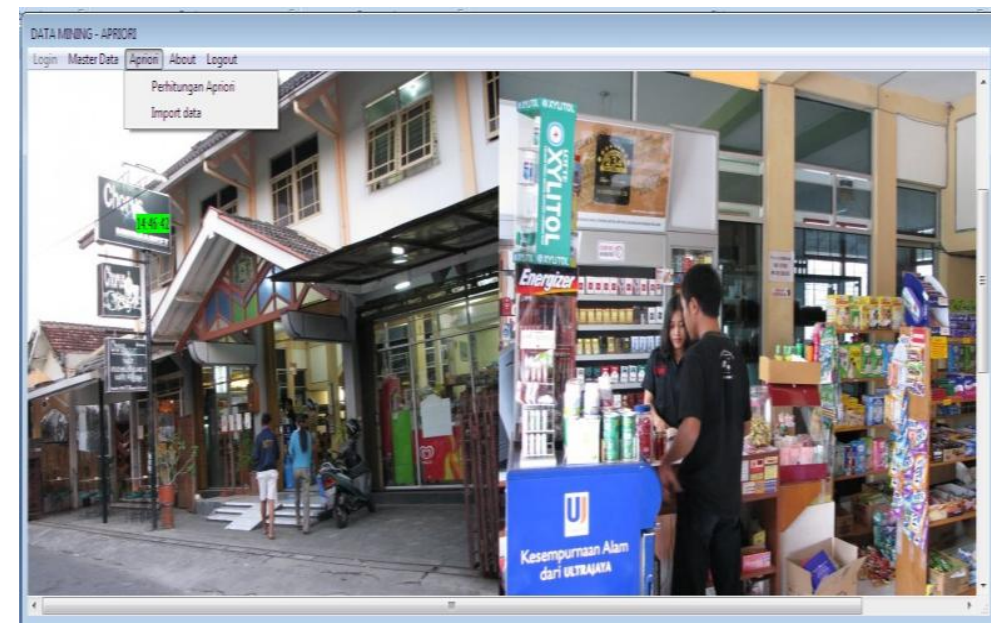

Gambar 7. Tampilan Menu Apriori

\section{Implementasi Perhitungan Apriori}

Pada form proses perhitungan apriori ini, terdapat tanggal transaksi yang berbentuk combo box, digunakan untuk memilih tanggal sesuai dengan kebutuhan dan user berhak memilih tanggal yang sudah disediakan pada form ini. Jika user telah memilih tanggal, maka user klik tombol proses untuk memproses datanya dan melihat hasil support 1-itemset (C1). Semua jumlah total transaksi akan terhitung secara otomatis pada saat pemilihan tanggal dilakukan. 
Tampilan yang muncul ketika tombol proses telah diklik adalah berupa DBGrid yang berupa kode barang, nama barang, jumlah dan nilai support. Dapat dilihat pada gambar 8 .

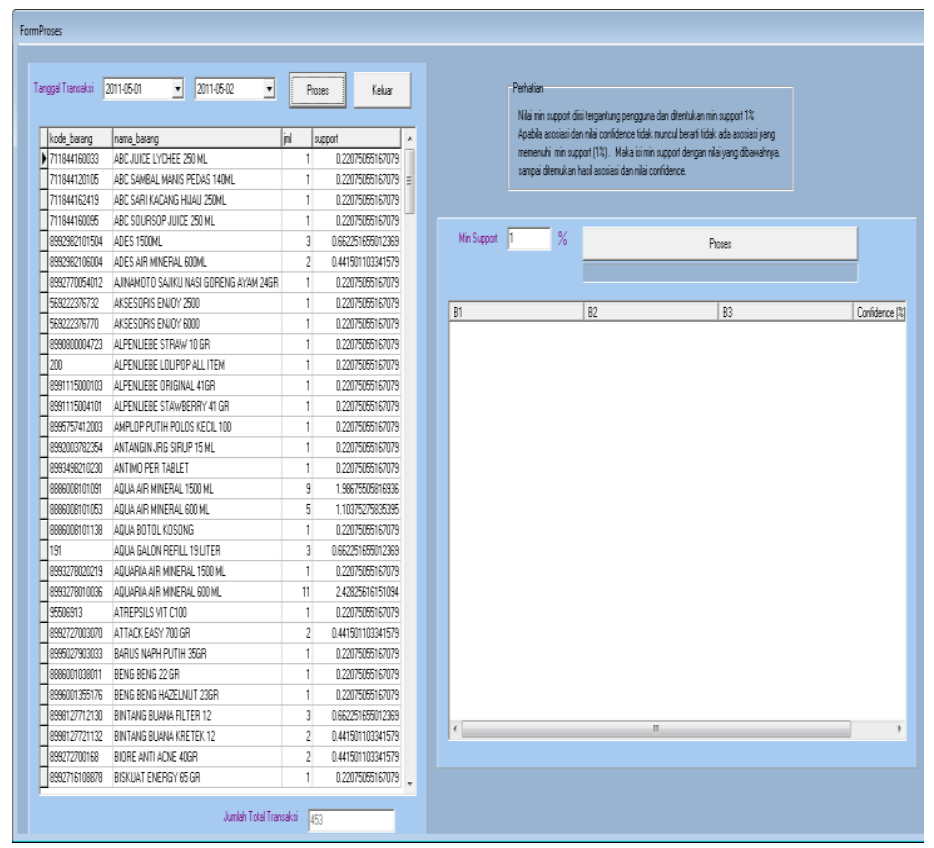

Gambar 8 Tampilan Form Hasil 1-itemset (C1)

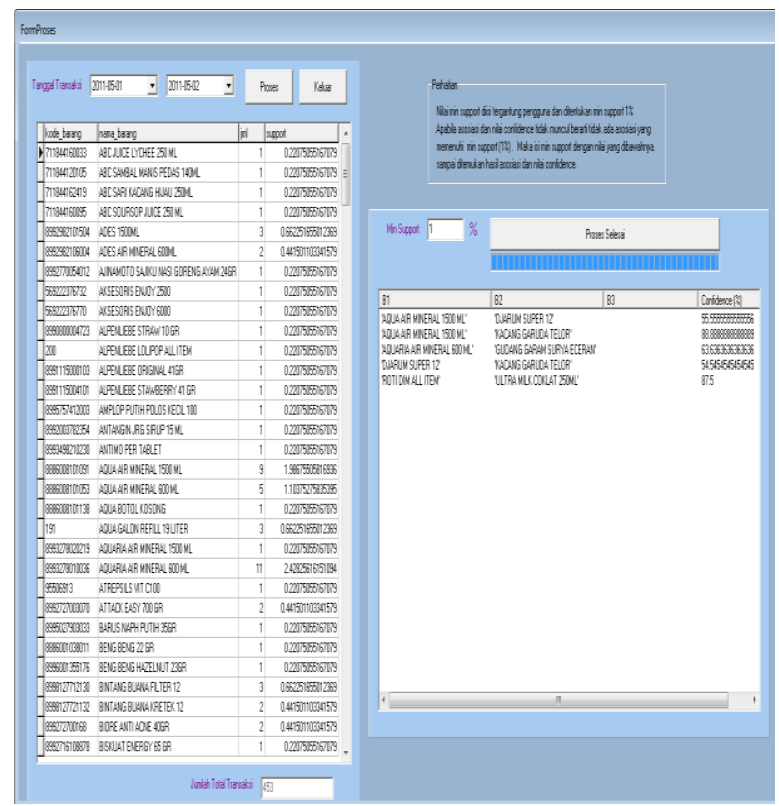

Gambar 9 Tampilan Form Hasil asosiasi dan nilai confidence (\%)

Terdapat min support berbentuk text yang digunakan untuk menentukan berapa presentase kombinasi item yang dimiliki sejumlah data transaksi dengan cara menentukan nilai minimum support. Dalam implementasi ini ditentukan min support $1 \%$. Ketika minimum support sudah ditentukan oleh pengguna berapa persen (\%) maka klik tombol Proses untuk mengetahui nilai confidence berapa 
persen (\%) serta hasil aturan asosiasi. Apabila proses masih berjalan akan muncul tulisan sedang proses pada tombol button dan apabila hasilnya muncul maka ada tulisan bahwa proses sudah selesai. Hasilnya akan muncul dalam bentuk tabel yang berisi B1, B2, B3 dan confidence. Apabila B3 tidak muncul, itu artinya tidak ada 3 item yang memenuhi min support 1\%. Tampilan Form hasil asosiasi dan nilai confidence dapat dilihat pada gambar 9

\section{Analisa Hasil}

Hasil sistem yang didapatkan harus diuji nilainya dengan membandingkan hasil pengujian sistem secara manual, sehingga dengan perbandingan ini akan didapatkan hasil sistem yang benar-benar sesuai dengan hitungan manualnya dan dapat dibandingkan dengan hasil dari perhitungan aplikasi. Tahap perhitungan yang diperlukan :

1. Mencari jumlah total transaksi dan nilai support.

2. Menentukan minimum support $1 \%$

3. Membentuk aturan asosiasi dan mencari nilai confidence sesuai dengan min support yang ditentukan yaitu $1 \%$.

Sebagai contoh analisa untuk melakukan perhitungan secara manual, diambil contoh data mining pada transaksi penjualan barang mulai dari tanggal $1 \mathrm{Mei}$ 2011 sampai 2 Mei 2011 yang berjumlah 453 data transaksi.

Tabel 1 Data Transaksi

\begin{tabular}{|l|c|c|l|l|c|}
\hline TANGGAL & $\begin{array}{c}\text { ID } \\
\text { TRANSAKSI }\end{array}$ & $\begin{array}{c}\text { NO } \\
\text { TRANSAKSI }\end{array}$ & KODE BARANG & NAMA BARANG & HARGA \\
\hline $5 / 1 / 2011$ & 1 & 1 & 8991906101019 & DJARUM SUPER 12 & 8900 \\
\hline $5 / 1 / 2011$ & 2 & 1 & 34 & FRUITAMIN/TEKITA & 1000 \\
\hline $5 / 1 / 2011$ & 3 & 1 & 89686010015 & $\begin{array}{l}\text { INDOMIE AYAM } \\
\text { BAWANG 69GR }\end{array}$ & 1400 \\
\hline $5 / 1 / 2011$ & 4 & 2 & 8886008101091 & $\begin{array}{l}\text { AQUA AIR MINERAL } \\
\text { 1500 ML }\end{array}$ & 2900 \\
\hline $5 / 1 / 2011$ & 5 & 2 & 8991906101019 & DJARUM SUPER 12 & 8900 \\
\hline
\end{tabular}

Penyelesaian perhitungan apriori sebagai berikut :

1. Mencari jumlah total transaksi dan nilai support.

Langkah awal dari yang dilakukan adalah dengan menghitung jumlah total data transaksi dari tanggal yang dibutuhkan oleh pengguna yaitu sebagai contoh tanggal 1 Mei 2011 sampai 2 Mei 2011.

Rumus untuk mencari nilai support 1 itemset adalah :

Support $=\quad$ Jumlah transaksi item B1 $\quad \times 100 \%$ Jumlah total transaksi

Keterangan : 
$\mathrm{B} 1$ = Jumlah barang satu item

Total transaksi $=$ Jumlah keseluruhan total transaksi tanggal 1-2 Mei

Setelah proses dijalankan maka akan muncul tabel seperti di bawah ini yang memiliki total transaksi 453 beserta nilai support:

Tabel 2 Satu Itemset(C1)

\begin{tabular}{|l|c|c|}
\hline \multicolumn{1}{|c|}{ B1 } & JML & SUPPORT \\
\hline ABC JUICE LYCHEE 250 ML & 1 & $1 / 453 * 100 \%=0.220750552 \%$ \\
\hline ABC SAMBAL MANIS PEDAS 140ML & 1 & $1 / 453 * 100 \%=0.220750552 \%$ \\
\hline ABC SARI KACANG HIJAU 250ML & 1 & $1 / 453 * 100 \%=0.220750552 \%$ \\
\hline ABC SOURSOP JUICE 250 ML & 1 & $1 / 453 * 100 \%=0.220750552 \%$ \\
\hline ADES 1500ML & 3 & $3 / 453 * 100 \%=0.662251656 \%$ \\
\hline ADES AIR MINERAL 600ML & 2 & $2 / 453 * 100 \%=0.441501104 \%$ \\
\hline
\end{tabular}

2. Menentukan minimum support $1 \%$.

Dari tabel diatas dapat dilihat hasil support dan ditentukan minimum support yaitu $1 \%$.

3. Menentukan frequent 1-itemset

Membuang itemset yang tidak memenuhi minimum support $1 \%$. Hasil frequent 1-itemset dapat dilihat pada tabel di bawah ini:

Tabel 3 Hasil Frequent 1-Itemset(L1) Min Sup 1\%

\begin{tabular}{|l|c|l|}
\hline \multicolumn{1}{|c|}{ NAMA BARANG } & JML & \multicolumn{1}{c|}{ SUPPORT } \\
\hline AQUA AIR MINERAL 1500 ML & 9 & $9 / 453 * 100 \%=1.986754967 \%$ \\
\hline AQUA AIR MINERAL 600 ML & 5 & $5 / 453 * 100 \%=1.103752759 \%$ \\
\hline AQUARIA AIR MINERAL 600 ML & 11 & $11 / 453 * 100 \%=2.428256071 \%$ \\
\hline DJARUM SUPER 12 & 11 & $11 / 453 * 100 \%=2.428256071 \%$ \\
\hline GUDANG GARAM SURYA ECERAN & 11 & $11 / 453 * 100 \%=2.428256071 \%$ \\
\hline KACANG GARUDA TELOR & 9 & $9 / 453 * 100 \%=1.986754967 \%$ \\
\hline KOREK GAS FIRESTONE/MAGNET & 8 & $8 / 453 * 100 \%=1.766004415 \%$ \\
\hline ROTI DIM ALL ITEM & 8 & $8 / 453 * 100 \%=1.766004415 \%$ \\
\hline ULTRA MILK COKLAT 250ML & 10 & $10 / 453 * 100 \%=2.207505519 \%$ \\
\hline
\end{tabular}

3.1 Mencari Frequent 2-itemset (L2) dengan mengkombinasikan frequent 1itemset. Rumus untuk mencari frequent 2-itemset adalah :

Support $=$ Jumlah item B1 dan item B2 x 100\%

Jumlah total transaksi

Keterangan : 
$\mathrm{B} 1$ = Kombinasi jumlah barang dua item (B1 dan B2)

Total transaksi $=$ Jumlah keseluruhan total transaksi tanggal 1-2 Mei

Setelah proses dijalankan maka hasil yang dilihat pada tabel 4 .

Tabel 4 Dua Itemset (C2) min support 1\%

\begin{tabular}{|c|c|c|c|}
\hline B1 & B2 & JML & SUPPORT \\
\hline $\begin{array}{l}\text { AQUA AIR } \\
\text { MINERAL } 1500 \mathrm{ML}\end{array}$ & $\begin{array}{l}\text { AQUA AIR MINERAL } 600 \\
\text { ML }\end{array}$ & 0 & $0 / 453 * 100 \%=0 \%$ \\
\hline $\begin{array}{l}\text { AQUA AIR } \\
\text { MINERAL } 1500 \mathrm{ML}\end{array}$ & $\begin{array}{l}\text { AQUARIA AIR MINERAL } \\
600 \mathrm{ML}\end{array}$ & 0 & $0 / 453 * 100 \%=0 \%$ \\
\hline $\begin{array}{l}\text { AQUA AIR } \\
\text { MINERAL } 1500 \mathrm{ML}\end{array}$ & DJARUM SUPER 12 & 5 & $\begin{array}{l}5 / 453 * 100 \%= \\
1.103752759 \%\end{array}$ \\
\hline $\begin{array}{l}\text { AQUA AIR } \\
\text { MINERAL } 1500 \mathrm{ML}\end{array}$ & $\begin{array}{l}\text { GUDANG GARAM } \\
\text { SURYA ECERAN }\end{array}$ & 0 & $0 / 453 * 100 \%=0 \%$ \\
\hline $\begin{array}{l}\text { AQUA AIR } \\
\text { MINERAL } 1500 \mathrm{ML}\end{array}$ & $\begin{array}{l}\text { KACANG GARUDA } \\
\text { TELOR }\end{array}$ & 8 & $\begin{array}{l}8 / 453 * 100 \%= \\
1.766004415 \%\end{array}$ \\
\hline $\begin{array}{l}\text { AQUA AIR } \\
\text { MINERAL } 1500 \mathrm{ML}\end{array}$ & $\begin{array}{l}\text { KOREK GAS } \\
\text { FIRESTONE/MAGNET }\end{array}$ & 4 & $\begin{array}{l}4 / 453 * 100 \%= \\
0.883002208 \%\end{array}$ \\
\hline
\end{tabular}

\subsection{Menentukan frequent 2-itemset}

Membuang itemset yang tidak memenuhi minimum support $1 \%$. Hasil frequent 2-itemset dapat dilihat pada tabel 5 .

Tabel 5 Hasil Frequent 2-Itemset(L2) Min Sup 1\%

\begin{tabular}{|l|l|c|c|}
\hline \multicolumn{1}{|c|}{ B1 } & \multicolumn{1}{|c|}{ B2 } & JML & \multicolumn{1}{c|}{ SUPPORT } \\
\hline $\begin{array}{l}\text { AQUA AIR MINERAL } \\
1500 \text { ML }\end{array}$ & DJARUM SUPER 12 & 5 & $5 / 453 * 100 \%=1.103752759 \%$ \\
\hline $\begin{array}{l}\text { AQUA AIR MINERAL } \\
1500 \text { ML }\end{array}$ & $\begin{array}{l}\text { KACANG GARUDA } \\
\text { TELOR }\end{array}$ & 8 & $8 / 453 * 100 \%=1.766004415 \%$ \\
\hline $\begin{array}{l}\text { AQUA AIR MINERAL } \\
\text { 600 ML }\end{array}$ & $\begin{array}{l}\text { GUDANG GARAM } \\
\text { SURYA ECERAN }\end{array}$ & 7 & $7 / 453 * 100 \%=1.545253863 \%$ \\
\hline DJARUM SUPER 12 & $\begin{array}{l}\text { KACANG GARUDA } \\
\text { TELOR }\end{array}$ & 6 & $6 / 453 * 100 \%=1.324503311 \%$ \\
\hline ROTI DIM ALL ITEM & $\begin{array}{l}\text { ULTRA MILK } \\
\text { COKLAT 250ML }\end{array}$ & 7 & $7 / 453 * 100 \%=1.545253863 \%$ \\
\hline
\end{tabular}

3.3 Mencari Frequent 3-itemset (L3) dengan mengkombinasikan frequent 1itemset dengan frequent 2-itemset. Apakah ada itemset yang memenuhi minimum support $1 \%$ pada 3-itemset? Hasil yang dilihat pada tabel 6 .

Tabel 6 Tiga Itemset (C3)

\begin{tabular}{|l|l|l|c|l|}
\hline \multicolumn{1}{|c|}{ B1 } & \multicolumn{1}{|c|}{ B2 } & \multicolumn{1}{|c|}{ B3 } & JML & \multicolumn{1}{|c|}{ SUPPORT } \\
\hline AQUA AIR MINERAL 1500 & AQUA AIR MINERAL 600 & AQUARIA AIR MINERAL & 0 & $0 / 453 * 100 \%=$ \\
ML & ML & 600 ML & $0 \%$ \\
\hline AQUA AIR MINERAL 1500 & AQUA AIR MINERAL 600 & DJARUM SUPER 12 & 0 & $0 / 453 * 100 \%=$ \\
ML & ML & & $0 \%$ \\
\hline AQUA AIR MINERAL 1500 & AQUA AIR MINERAL 600 & GUDANG GARAM & 0 & $0 / 453 * 100 \%=$ \\
ML & ML & SURYA ECERAN & $0 \%$ \\
\hline
\end{tabular}


Pencarian dapat diberhentikan karena didapatkan hasil support 0\% pada C3. Ini berarti tidak ada asosiasi barang yang memenuhi min support yang ditentukan (1\%). Maka yang memenuhi min support $1 \%$ adalah frequent 2itemset.

4. Membentuk aturan asosiasi dan mencari nilai confidence (\%)

Rumus untuk mencari nilai confidence adalah:

Confidende $=$ Jumlah transaksi item $\mathrm{B} 1$ dan item $\mathrm{B} 2 \quad \mathrm{x} 100 \%$

Jumlah transaksi item B1

Keterangan : B1 dan B2 = Jumlah kombinasi barang 1 dan 2 (B1 dan B2) terhadap transaksi

B1 = Jumlah barang satu item (B1) terhadap transaksi

Tabel 7 Hasil Asosiasi dan Nilai Confidence 1\%

Dari implementasi ini dapat dilihat dapat diambil kesimpulan hasil asosiasi

\begin{tabular}{|l|l|l|}
\hline \multicolumn{1}{|c|}{ B1 } & \multicolumn{1}{|c|}{ B2 } & \multicolumn{1}{c|}{ Confidence $(\%)$} \\
\hline $\begin{array}{l}\text { AQUA AIR MINERAL } \\
\text { 1500 ML }\end{array}$ & DJARUM SUPER 12 & $5 / 9 * 100 \%=55.55555556 \%$ \\
\hline $\begin{array}{l}\text { AQUA AIR MINERAL } \\
\text { 1500 ML }\end{array}$ & $\begin{array}{l}\text { KACANG GARUDA } \\
\text { TELOR }\end{array}$ & $8 / 9 * 100 \%=88.88888889 \%$ \\
\hline $\begin{array}{l}\text { AQUA AIR MINERAL } \\
\text { 600 ML }\end{array}$ & $\begin{array}{l}\text { GUDANG GARAM } \\
\text { SURYA ECERAN }\end{array}$ & $7 / 11 * 100 \%=63.63636364 \%$ \\
\hline DJARUM SUPER 12 & $\begin{array}{l}\text { KACANG GARUDA } \\
\text { TELOR }\end{array}$ & $6 / 11 * 100 \%=54.54545455 \%$ \\
\hline ROTI DIM ALL ITEM & $\begin{array}{l}\text { ULTRA MILK COKLAT } \\
\text { 250ML }\end{array}$ & $7 / 8 * 100 \%=87.5 \%$ \\
\hline
\end{tabular}

dan nilai confidence yang memenuhi min support $1 \%$ yaitu :

1. Jika pelanggan membeli Aqua Air Mineral $1500 \mathrm{Ml}$ maka juga membeli Djarum Super 12 dengan nilai confidence $55.55555556 \%$.

2. Jika pelanggan membeli Aqua Air Mineral $1500 \mathrm{Ml}$ maka juga membeli Kacang Garuda Telor dengan nilai confidence $88.88888889 \%$

3. Jika pelanggan membeli Aqua Air Mineral $600 \mathrm{Ml}$ maka juga membeli Gudang Garam Surya Eceran dengan nilai confidence $63.63636364 \%$

4. Jika pelanggan membeli Djarum Super 12 maka juga membeli Kacang Garuda Telor dengan niai confidence $54.54545455 \%$

5. Jika pelanggan membeli Roti Dim All Item maka juga membeli Ultra Milk Coklat $250 \mathrm{ml}$ dengan nilai confidence $87.5 \%$.

\section{Kesimpulan}

1. Hasil dari association yang berupa informasi mengenai barang apa saja yang dibeli secara bersamaan oleh konsumen, dapat digunakan sebagai bahan pertimbangan untuk menetapkan strategi pemasaran. 
2. Pada data transaksi penjualan yang ada di Chorus Minimarket, dapat di hasilkan aturan tentang hubungan asosiasi antar barang yang biasanya di beli oleh pelanggan secara bersamaan.

3. Aplikasi data mining dengan apriori dapat di selesaikan dengan menggunakan program Delphi dan menggunakan database postgreSQL.

\section{Saran}

1. Menggunakan komputer dengan kemampuan komputasi yang tinggi untuk mengolah data supaya lebih cepat.

2. Aplikasi ini dikembangkan lagi jika user dapat melihat nilai confidence dari barang yang ditentukan oleh manajer sendiri.

\section{DAFTAR PUSTAKA}

Han, Jiawei. dan Kamber, M., 2001, Data Mining : Concepts and Techniques, Morgan Kaufman Publisher. San Fransisco.

HM.,Jogiyanto, 2005, Analisis dan Desain Sistem Informasi: Pendekatan Teori dan Praktek Aplikasi Bisnis. CV. Andi Offset. Yogyakarta.

Kantardzic, M., 2003. Data Mining : Concepts, Models, Methods and Algorithms. John Wiley and son.

Kusrini dan Luthfi, E.T, 2009, Algoritma Data Mining. CV.Andi Offset. Yogyakarta.

Santoso, Budi, 2007, Data Mining : Pemanfaatan Data untuk Keperluan Bisnis. Graha Ilmu. Yogyakarta.

Turban, Efram, Aronson, Jay E, dan Peng-Liang, Ting, 2005, Decision Support Systems and Intelligent Systems (Sistem Pendukung Keputusan dan Sistem Cerdas). CV. Andi Offset. Yogyakarta. 